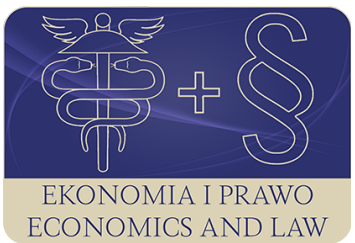

EKONOMIA I PRAWO. ECONOMICS AND LAW

Volume 20, Issue 3, September 2021

p-ISSN 1898-2255, e-ISSN 2392-1625

www.economicsandlaw.pl

ORIGINAL ARTICLE

received 30.03.2021; revised 10.09.2021; accepted 30.09.2021

Citation: Pyka, I., Nocoń, A., \& Muszyński, M. (2021). The role of capital adequacy standards

in creating financial safety of the bank: the evaluation and analysis of the survey results. Ekonomia i Prawo. Economics and Law, 20(3), 641-657. https://doi.org/10.12775/EiP.2021.038.

\title{
The role of capital adequacy standards in creating financial safety of the bank: the evaluation and analysis of the survey results
}

\author{
IRENA PYKA \\ University of Economics in Katowice, Faculty of Finance, Department of Banking and Financial \\ Markets, Poland \\ $\square$ irena.pyka@ue.katowice.pl \\ orcid.org/0000-0001-5524-3550

\section{ALEKSANDRA NOCOŃ} \\ corresponding author \\ University of Economics in Katowice, Faculty of Finance, Department of Banking and Financial \\ Markets, ul. 1 Maja 50, 40-287 Katowice, Poland \\ ■aleksandra.nocon@ue.katowice.pl \\ (D) orcid.org/0000-0003-3250-2382

\section{MATEUSZ MUSZYŃSKI} \\ University of Economics in Katowice, Faculty of Finance, Department of Banking and Financial \\ Markets, Poland \\ $\square$ mateusz.muszynski@ue.katowice.pl \\ (D) orcid.org/0000-0001-8722-5541
}

\begin{abstract}
Motivation: After the global financial crisis, banks' financial safety has been considered as a public good and put under closer control and supervision. The prudential regulations of credit institutions which are the main subject of the study, have been significantly tightened. Although the minimum level of banks' own funds, set adequately to the risk, had been a fundamental indicator of banks' financial safety since the end of 1980s, after the global financial crisis the quality of this capital has changed and the scope of its
\end{abstract}


regulation has been increased. By respecting the new prudential standards of the Basel Committee on Banking Supervision at the international level, financial safety of the banks has been additionally put under the macro-supervision. The concern about the overregulation of the banking system raises many controversies, what justifies conducting research on this subject.

Aim: The main purpose of the article is to identify changes in the bank's strategies of creating financial safety after the global financial crisis, considering macro- and micro-prudential regulations, aimed at strengthening the level and quality of bank capital, based on the results of the conducted research.

Results: The results of the empirical research indicate that there is a strong belief among management staff in commercial banks in Poland that the increase in the level and structure of the own funds in credit institutions rises their financial safety. The results confirm the intensification of the process of implementing Basel regulations in commercial banks in Poland.

Keywords: financial safety; quality of the own funds; capital adequacy standards; capital buffers JEL: G01; G21; G28

\section{Introduction}

The main subject of this research are the new capital regulations for credit institutions imposed within the Basel III regulatory framework. Since the late 1980's the minimum level of the bank's own funds set adequately to their risk has been the fundamental indicator of banks' financial safety. After the global financial crisis the capital standards for banks have been tightened. Moreover, the quality of bank capital, necessary to absorb the losses from the operational activity, has also changed.

The research conducted in this area, based on the complex analysis of new prudential regulations let formulate the hypothesis stating that an increase in the level and quality of bank capital contributes to increasing the level of bank's financial safety. To verify the adopted hypothesis research addressed to the management staff in commercial banks in Poland (so-called domestic banks) have been conducted.

Article has been divided into theoretical and empirical part. The theoretical part concentrates on the changes in the banks' strategies of creating their financial safety, which occurred after the global financial crisis and puts a strong emphasis on the new role of the bank capital. At the same time, by analyzing the macro- and micro-prudential regulations designed to strengthen the amount and quality of the bank capital, Authors present the controversies arising around the new doctrine of bank's financial safety. The empirical part of the paper describes and evaluates the results of the survey and confronts them with the discussed theoretical assumptions. 


\section{Literature review}

\subsection{Post-crisis attributes of the bank's financial safety}

Maintaining the bank's financial safety has always been and still remains an important determinant of country's monetary equilibrium and the financial stability of the economy (Flejterski, 2008, p. 17). Due to the financial systems' globalization, financial safety of the bank is increasingly considered as a public good (Koleśnik, 2011, p. 51; Mitręga-Niestrój, 2008, pp. 31-32). Strong arguments to give this status to the financial safety have for the first time occurred during the global financial crisis. Significant financial support was offered to credit institutions which may be described as the collective consumption of the global society, aimed at bringing back the financial safety to the world economy. The consequence of the new view on financial safety has undoubtedly been the post-crisis introduction of macro-prudential supervisory regulations, aimed at identifying, analyzing and monitoring the systemic risk. This risk has been recognized as the main reason for the destabilization of financial systems during the economic recession of the 21st century. Financial institutions, including all banks, were covered by the macro-prudential supervision (Pyka et al., 2019b, p. 1l) what modified at the same time a set of tools and methods applied to maintain their financial safety (see Scheme 1).

The micro-prudential regulations, which were first established at the end of the 1980s, remained an important pillar of the bank's financial safety. Financial safety, identified till that time with the bank's solvency, so as the situation when the market value of the credit institution assets exceeds the value of its liabilities, has been then standardized and the solvency function has been assigned to the minimum level of the regulatory capital. It has been agreed that safe banks should keep sufficient amount of capital to cover their both current and future liabilities weighted by risk of their financial assets (Pyka, 2013, pp. 22-23). Basel Committee on Banking Supervision has repeatedly modified the capital adequacy ratio used for the calculation of the minimum regulatory capital requirement ${ }^{1}$. The approach to the methods of calculating the minimum

${ }^{1}$ Basel Capital Accord (Basel I) was published in 1998 and implemented the capital adequacy ratio to the set of existing prudential rules. Initially its calculation was based only on the credit risk and its rate was set at $8 \%$. After the currency crises in the 90 s and the collapse of the British Barings Bank, in 1996 the method of calculating the capital adequacy ratio was changed. The new method was extended by market risk, including foreign exchange risk and interest rate risk, as key from the point of view of exposure to bank risk (BIS, 1996). Basel II (New Capital Accord) additionally modified the calculation of the capital adequacy ratio by identifying three main risks for the bank's activity — credit risk, market risk and operational risk (not included previously). Basel II has also introduced the possibility to choose between standardized and advanced approaches of calculating the capital adequacy ratio (BIS, 2004). In 2006 the extended version of Basel II has been published (also called as Basel 2.5), in which the previous recommendations for the calcu- 
capital requirement has also been changed several times. In the new post-crisis regulations, the bank's financial safety was additionally based on increasing the quality of regulatory capital and the reduction of the financial leverage (BIS, 2010, pp. 22-23). The implemented changes undoubtedly indicate that the regulatory capital does not properly fulfill its financial safety function. For these reasons, there are many critical remarks to the new concept of the bank's financial safety. The main caveats to the current micro-prudential regulations are as follows:

- rising overhead costs in credit institutions due to stricter prudential regulations;

- negative changes in the banks' operational activity, including lower effectiveness and the redefinition of the business model;

- international financial institutions under the macro-prudential supervision and resolution do no guarantee the reduction of the systemic risk in the banking sector and in the financial system.

Many critical remarks are also addressed to the financial safety of the banks subordinated to the macro-prudential policy. Credit institutions formulate them not only because of the introduction of the external supervision after the financial crisis. Antagonisms have been also diagnosed in the conceptual, institutional and instrumental dimension of the macro-prudential policy (Pyka et al., 2019a, p. 87). The main caveats to the macro-prudential policy are as follows:

- lack of coordination between the state-level supervisory policy, monetary policy and fiscal policy;

- broad and multidimensional influence of the macro-prudential policy on financial stability;

- "soft" and cyclical nature of the instruments of the macro-prudential policy;

- low efficiency of the macro-prudential instruments in mitigating the systemic risk, due to difficulties with its identification and measurement;

- rising opportunity costs of the regulatory compliance in credit institutions, which enhance the development of the shadow banking.

Scope, intensity and the nature of changes in creating the financial safety together with the innovative character of the regulatory instruments and the progressive institutionalization of the safety net raise many concerns about the possible overregulation and high social costs of new regulations. These assumptions justify the scientific research in this area but at the same time they indicate that the increase in the level and quality of bank capital is not a sufficient guarantee for the financial safety of credit institutions.

lation of capital adequacy have been amended, including rules for market risk and the construction of the minimum capital requirements (BIS, 2006). 


\subsection{Changes to the capital adequacy standards of the commercial banks in Poland}

The main impulse for changes in the capital adequacy standards of credit institutions became the recommendations of the Basel Committee on Banking Supervision implemented in 2010 and presented in the Basel III Accord (BIS, 2010). These arrangements, which were transposed into the European Union legal framework in the form of the CRD IV/CRR package (Directive 2013/36/ EU, 2013; Regulation (EU) No 575/2013, 2013), entered into force in the Polish banking sector on January 1, 2014. In general, all EU Member States, including Poland, have been obliged to implement the CRD IV Directive to the national law. In turn, the CRR Regulation was implemented directly in EU Member States, without a need for additional legal changes in individual jurisdictions ${ }^{2}$.

The implementation of the CRD IV/CRR package into the Polish legislation has been made primarily in the form of the amendment to the Banking Law Act made by the Act on macroprudential supervision over the financial system and crisis management $(2015)^{3}$. These changes have implemented to the Act new provisions of the CRD IV Directive (not existed in the previous CRD Directives) as well as modifications of those which have been changed. Moreover, there were introduced standards which adapted the national law to the solutions included in the CRR Regulation. Through the amendment to the Banking Law Act the following existing definitions have been removed: own funds, core and supplementary funds, as well as the capital adequacy ratio, replacing them by numerous references to specific provisions of the Regulation.

To fully implement European regulations into the Polish legal framework, executive acts to the Banking Law Act were also required in the form of ordinances of the Minister of Finance, which replaced the existing resolutions of the Polish Financial Supervision Authority in this respect, as well as letters of the Polish Financial Supervision Authority to the banking sector, regarding the CRD IV/CRR package (KNF, 2017). In order to ensure the fullest possible implementation of the solutions adopted in the above mentioned package, under the system-wide of the Polish legal framework the mechanism of cooperation between the Polish Financial Supervision Authority and the Minister competent for financial institutions is envisaged in issuing all lower-order acts (Act on macroprudential supervision over the financial system and crisis man-

${ }^{2}$ However in practice, regulation included in the Directive are implemented by individual EU countries with the possibility of adapting them to the specificity of a given country, provided that at least the requirements contained in the document are met. While, regulations of the Regulation are directly applicable and therefore cannot be subject of any changes by national supervisors (Pyka et al., 2019a, p. 78).

3 The Act on macroprudential supervision over the financial system and crisis management (2015) implements in particular regulations regarding capital buffers: Conservation Buffer, Countercyclical Buffer, Systemically Important Institutions Buffers and Systemic Risk Buffer. 
agement, 2015). The CRD IV Directive and the CRR Regulation implemented in the Polish banking sector were designed to strengthen the capital safety through (Marcinkowska et al., 2014, p. 52):

- increasing quality and transparency of the capital base of banking institutions: ensuring greater ability to absorb losses both during activity and after cessation of operations;

- extension of the scope of risk types included in the capital standard: in addition to previously implemented solutions for the trading portfolio and securitization transactions, the new capital requirements also referred to the counterparty credit risk arising from derivative transactions, repo transactions and securities financing;

- implementation of the standards for capital buffers creation and a more forward-looking approach to reserves creation: which were supposed to reduce the current procyclical nature of regulations, as well as limit the impact of shocks, and thus favor an increase of banking sector stability and reduction of its vulnerability to external shocks ${ }^{4}$.

In the post-crisis regulations a new definition of regulatory capital was proposed, which included the highest quality components of bank's capital, to fully cover exposures at risk. The regulatory capital was represented by the sum of I and II category of capital ${ }^{5}$. Therefore, capital strengthening of banks was based on giving greater significance to Tier 1 capital, which a share in the structure should be at least equal to $75 \%$, and which was intended to cover current losses. In turn, Tier 2 capital was designed to satisfy creditors in case of the bank's bankruptcy. Thus, Tier 3 capital implemented in the previous Basel Accord (The New Basel Capital Accord) and included so far in the regulatory capital was abolished. Therefore, the criteria for recognizing components of the bank's capital as own funds were tightened up by specifying conditions that must be met by both components of core and supplementary funds. At the same time, raising the quality of banks' own capital meant increasing capital requirements (Lepczyński, 2013, p. 7).

The new capital recommendations were also reflected in the changed set of capital adequacy ratios, referring to the activity of individual banks as well as the whole sector. The CRR Regulation distinguishes three capital adequacy ratios which are applicable to credit institutions (see Table 1).

${ }^{4}$ In addition, the provisions of the CRD IV/CRR package introduced the leverage ratio as a supplementary measure for the capital adequacy ratio as well as minimum liquidity standards and measures enabling monitoring and assessment of liquidity risk (LCR and NSFR).

5 Basel III distinguished the following categories of own funds: (1) Tier l capital: bank's core capital which is referred as business continuity capital, covering ordinary share capital Tier 1, also known as Common Equity Tier 1 (CETl) as well as Additional Tier 1 capital, which includes some types of hybrid instruments; (2) Tier 2 capital: defined as bank's supplementary capital, including subordinated loans, as well as certain categories of reserves (general risk provisions and excess reserves over expected losses for the loan portfolio). 
Furthermore, the Basel III identified among the Tier 1 capital additional category of capital - Common Equity Tier 1 (CETl), which was primarily composed of common stock (share capital). Tier 1 Capital Ratio was raised. While, the total capital ratio remained unchanged.

The extension of post-crisis capital requirements - to additionally strengthen banks' financial safety - was also the implementation of capital buffers, including:

- Countercyclical Capital Buffer (CСyB): an additional capital requirement imposed on banks to reduce systemic risk, arising from the credit cycle;

- Global Systemically Important Financial Institutions Buffer (G-SII): regarding major financial institutions that may create systemic risk;

- Other Systemically Important Financial Institutions Buffer (O-SII): regarding other financial institutions that may create systemic risk;

- Systemic Risk Buffer (SRB): to prevent and reduce long-term non-cyclical or macroprudential risk.

Table 2 presents the minimum level of particular capital buffers specified in Polish legislation compared to the regulations included in the CRD IV/CRR package (see Table 2).

The Countercyclical Conservation Buffer is implemented by the macroprudential supervision authority during excessive credit growth and phased out during economic slowdown. On the one hand, it is supposed to limit the scale of expansion during recovery, and at the same time create a capital base in the case of recession. The value of the buffer should take into account credit cycle and the risk resulting from excessive growth of banks' lending as well as national economic conditions. Systemically Important Financial Institutions buffers - on a global scale (G-SII) and within local jurisdictions (O-SII) have also become new instruments, imposed on large financial institutions that may create systemic risk.

On December 11, 2017, due to still identified regulatory weaknesses, affecting financial safety of banks, assumptions of the next Basel Accord - Basel IV (which complement imperfections of Basel III) were announced. In response to the new recommendations of the Basel Committee on Banking Supervision, the final text of the CRD V/CRR II package (Directive (EU) 2019/878, 2019; Regulation (EU) 2019/876, 2019) was published on June 7, 2019, which is intended to complement the previous reform program, and at the same time increase resilience of banks and credit institutions to possible shocks. The changes in capital adequacy standards, included in the new package concern:

- more risk-sensitive approach for the calculation of the capital requirements;

- changes in calculation the value of exposure in the capital requirement algorithm due to counterparty credit risk;

- modification of the rules for calculation the capital requirement for market risk;

- implementation of the TLAC (Total Loss-Absorbing Capacity) into the European legal framework; 
- increasing flexibility of the systemic risk buffer, including possibility of its imposition on all or only specific exposures;

- implementation of an algorithm for calculating the systemic risk buffer;

- a new definition of global systemically important financial institutions (GSIIs) relevant for introduction of the G-SII buffer in specific institutions;

- increasing the maximum level of other systemically important financial institutions buffer (O-SII buffer) from $2 \%$ to $3 \%$, but with the approval of the European Commission, it is possible to implement the buffer exceeding $3 \%$.

However, adjustment of the Polish regulations to the requirements of the EU package on capital requirements for financial institutions requires a re-amendment of the Banking Law Act and other laws.

The new capital adequacy standards implemented in international environment and then transposed into national law, although in assumptions of its applicants are supposed to increase financial safety of banks, undoubtedly impact on conditions of banking activity and as a consequence, affect decisions taken by bank managers. They also determine the methods of financial risk management and the approach to appropriate level of capital collateral. The permanent evolution of prudential regulations when it comes to capital adequacy is a result of changing conditions for banks' functioning and growing systemic risk. However, the new capital adequacy standards are not without an impact on a level and structure of banks' capital collateral, which may also change the perspective of perceiving bank risk in the future.

\section{Methods}

The empirical research has been conducted by the use of the survey method. The research tool for the data acquisition was an online questionnaire which included 29 Likert scale questions with five response alternatives: strongly disapprove (1), disapprove (2), undecided (3), approve (4), and strongly approve (5).

The research was addressed to commercial banks' employees dealing directly with the financial risk management. The questionnaire has been delivered to 110 participants. The electronic data collection efforts resulted in the response rate of $100 \%$. Almost half $(49 \%)$ of the respondents represent the managerial positions, while $81 \%$ of the surveyed have been working for one institution for longer than 11 years and observing the changes in the risk management process before and after the last financial crisis. The limitation of the target group was dictated by the specialist knowledge for the discussed issues. Other criteria for selecting respondents were not taken into account as it has been stated that they are of secondary importance for the representativeness of the sample. It has been assumed that the credibility of the results will depend mainly on the seniority of the employees and their position in the organizational structure of the bank.

The data obtained in the research has been tested for the reliability which refers to the consistency across the parts of the measuring instrument. The most 
commonly used internal consistency measure for the Likert scales is the Cronbach Alpha coefficient (Taherdoost, 2016, p. 33). A scale indicates high internal consistency reliability when the Cronbach Alpha is higher than 0,7. The indicator calculated for the research exceeds the minimum required level and thus confirms the reliability of the designed questionnaire (see Table 3).

The applied research method enabled both qualitative and quantitative exploration of the research problem, let the Authors confront the obtained results with the performed theoretical study and identify the dependencies between the financial safety of credit institutions and the new capital adequacy regulations.

\section{Results}

The complete survey questionnaire included 29 questions. Following the specific research goal, the number of questions presented in the analysis has been limited to 6.

Question no 1: After the global financial crisis, the number of prudential regulations applied in banks has risen (see Chart l). The aim of this question was to verify to what extent the new prudential regulations have been implemented by credit institutions in Poland. The vast majority of the surveyed population (95 percent) confirm that the number of the prudential regulations adopted in their institutions has risen. 5 percent remain undecided, while only 1 percent share the opposite opinion.

Question no 2: Implementation of the new prudential standards in banks helps reducing the intensity of the systemic risk (see Chart 2). The prudential regulations have been introduced to mitigate the systemic risk in the financial system. The purpose of this question was to verify how this process is viewed by the Polish bank managers. The majority of surveyed (72 percent) agree that new prudential regulations reduce the potential systemic risk. One in ten respondents disagrees with this statement and the rest is undecided.

Question no 3: New prudential regulations increase the level of bank capital (see Chart 3). According to the new capital adequacy standards, all credit institutions should raise the level of capital proportionately to the scale, nature and risk of their business activities. The aim of this question was to verify how the new prudential regulations influence the amount of capital in the Polish banking sector. The majority of the respondents claim that strengthening capital requirements improves the amount of capital in their institutions. However, 15 percent of respondents do not share this view, while 31 percent are undecided.

Question no 4: New prudential regulations contribute to the change in the structure (quality) of bank capital (see Chart 4). The majority of the surveyed (72 percent) indicate that new prudential regulations contribute not only to the increase in the level of capital but also to its structure, by improving its quality. 6 percent of respondents share the opposite view, while 22 percent are undecided. 
Question no 5: New prudential regulations contribute to the increase of the capital adequacy (see Chart 5). Survey research has also referred to the capital adequacy and thus covering the risk with an appropriate level and structure of capital. 72 percent of the surveyed claim that new prudential regulations contribute to the increase of the capital adequacy. Only 5 percent of the surveyed population do not share this view, while 23 percent are undecided. This means that the majority of banks in Poland cover the undertaken risk by the appropriate level of capital.

Question no 6: Under the influence of new prudential regulations, the interest in transferring risk in banks is rising (see Chart 6). The answers for this question indicate that due to new prudential regulations, domestic banks are more interested in the risk transfer. The majority of the respondents (79 percent) confirm this dependence. It means that new prudential regulations encourage banks to reduce retention of the risk and to transfer it to other institutions. 4 percent of the respondents disagree with this statement and 17 percent are undecided.

\section{Conclusion}

The research results indicate that the management staff in the commercial banks in Poland believes that a growth of the level and structure of the own funds in credit institutions increases their financial safety. Surveyed confirm that the number of prudential regulations implemented in the domestic institutions has significantly risen after the global financial crisis. However, their opinions are divided into two groups what seems to inform that the introduction of capital regulations is connected with the optimization of the bank risk. To some extent respondents confirm this by the identification of an increase of the domestic banks' own funds. However, only half of them indicate that the increase in the level of bank capital is caused by the implementation of new prudential regulations. The other respondents were highly dispersed in their opinions. It shows that the management staff seems to be more interested in enhancing financial efficiency of the banks than in adjusting their business models to the stricter capital requirements. At the same time, opinions about the capital adequacy can be also divided into two groups. The majority of the respondents confirm the rising capital adequacy. The rest of the surveyed judge this growth differently. Obtained results also suggest that the majority of the domestic banks cover the risk by the sufficient amount of capital, which means that they positively judge their financial safety.

Surveyed have also confirmed changes in the quality of the own funds caused by the prudential regulations. Almost 50 percent notice these changes, but the assessment of their dynamics differ between the respondents. The reason for this might be the previously mentioned changes to the new business models. The argument supporting the expected effects of the implementation of Basel capital regulations is the growing interest in the transfer of bank risk. The ma- 
jority of the respondents indicate that the adjustments to the new prudential regulations encourage banks to transfer some of their risk to other institutions.

Taking into account that 72 percent of the respondents agree that the implementation of the prudential regulations helps mitigating the systemic risk, it can be assumed that the measures aimed at increasing the financial safety of the banks in Poland are well received and based not only on the own funds. Respondents see the chances to improve the financial safety of the banks in transferring the risk outside the banking sector and in the mobility of the capital buffers.

\section{References}

BIS. (1996). Amendment to the capital accord to incorporate market risks. Retrieved 10.06.2020 from https://www.bis.org/publ/bcbs24.pdf.

BIS. (2004). International convergence of capital measurement and capital standards: a revised framework. Retrieved 11.06.2020 from https://www.bis.org/ publ/bcbs107.pdf.

BIS. (2006). International convergence of capital measurement and capital standards: a revised framework comprehensive version. Retrieved 11.06.2020 from https://www.bis.org/publ/bcbsl28.pdf.

BIS. (2010). Basel III: a global regulatory framework for more resilient banks and banking systems. Retrieved 17.04.2020 from https://www.bis.org/publ/ bcbs189.pdf.

Directive (EU) 2019/878 of the European Parliament and of the Council of 20 May 2019 amending Directive 2013/36/EU as regards exempted entities, financial holding companies, mixed financial holding companies, remuneration, supervisory measures and powers and capital conservation measures (OJ L 150, 7.6.2019).

Directive 2013/36/EU of the European Parliament and of the Council of 26 June 2013 on access to the activity of credit institutions and the prudential supervision of credit institutions and investment firms, amending Directive 2002/87/EC and repealing Directives 2006/48/EC and 2006/49/EC (OJ L $176,27.6 .2013)$.

Flejterski, S. (2008). Zaufanie do instytucji bankowo-finansowych jako fundament stabilnego systemu finansowego. In J. Nowakowski, \& T. Famulska (Eds.), Stabilność i bezpieczeństwo systemu bankowego. Difin.

KNF. (2017). Pakiet CRD IV/CRR: zmiany polskich regulacji. Retrieved 16.04.2020 from https://www.knf.gov.pl/dla_rynku/pakiet_crd4/ zmiany_polskich_regulacji_CRDIV.

Koleśnik, J. (2011). Bezpieczeństwo systemu bankowego: teoria i praktyka. Difin.

Lepczyński, M.(2013). Nowe regulacje w zakresie adekwatności kapitałowej i płynności banków wobec zagrożeń związanych z finansowaniem portfeli kredytów mieszkaniowych w polskich bankach. Zarządzanie i Finanse, $11(1 / 2), 341-355$. 
Marcinkowska, M., Wdowiński, P., Flejterski S., \& Zygierewicz M. (2014). Wpływ regulacji sektora bankowego na wzrost gospodarczy: wnioski dla Polski. Materiaty i Studia, 305, 1-229.

Mitręga-Niestrój, K. (2008). Znaczenie Bazylejskiego Komitetu Nadzoru Bankowego w global governance. In J. Nowakowski, \& T. Famulska (Eds.), Stabilność i bezpieczeństwo systemu bankowego (pp. 29-39). Difin.

Pyka, I. (2013). Bankowość komercyjna. Uniwersytet Ekonomiczny w Katowicach.

Pyka, I., Nocoń, A., \& Cichorska, J. (2019a). Nowy tad regulacyjny w sektorze bankowym Unii Europejskiej. CeDeWu.

Pyka, I., Zygierewicz, M., Bolibok, P., \& Nocoń A. (2019b). Polityka makroostrożnościowa $w$ regulowaniu stabilności sektora bankowego: innowacyjność, implementacja, bariery. Uniwersytet Ekonomiczny w Katowicach.

Regulation (EU) 2019/876 of the European Parliament and of the Council of 20 May 2019 amending Regulation (EU) No 575/2013 as regards the leverage ratio, the net stable funding ratio, requirements for own funds and eligible liabilities, counterparty credit risk, market risk, exposures to central counterparties, exposures to collective investment undertakings, large exposures, reporting and disclosure requirements, and Regulation (EU) No 648/2012 (OJ L 150, 7.6.2019).

Regulation (EU) No 575/2013 of the European Parliament and of the Council of 26 June 2013 on prudential requirements for credit institutions and investment firms and amending Regulation (EU) No 648/2012 (OJ L 176, 27.6.2013).

Rozporządzenie Ministra Finansów z dnia 18 marca 2020 r. uchylające rozporządzenie $\mathrm{w}$ sprawie bufora ryzyka systemowego [Regulation of the Minister of Finance of March 18, 2020, repealing the ordinance on the systemic risk buffer] (Dz.U. 2020 poz. 473) (Poland).

Taherdoost, H. (2016). Validity and Reliability of the Research Instrument. How to Test the Validation of a Questionnaire/Survey in a Research. International Journal of Academic Research in Management, 5(3), 28-36.

Ustawa z dnia 5 sierpnia 2015 r. o nadzorze makroostrożnościowym nad systemem finansowym i zarządzaniu kryzysowym w systemie finansowym [Act of 5 August 2015 on macroprudential supervision over the financial system and crisis management] (Dz.U. 2015 poz. 1513) (Poland).

\section{Acknowledgements}

Author contributions: authors have given an approval to the final version of the article. Authors contributed to this work as follows: I.P. developed the concept and designed the study, A.N. and M.M. collected the data, A.N. and M.M. analysed and interpreted the data, I.P., A.N. and M.M. prepared the draft of the article, I.P., A.N. and M.M. revised the article critically for important intellectual content.

Funding: this research was fully funded by the University of Economics in Katowice.

Note: the results of this study were presented at the 8th International Conference Sustainable Finance \& Accounting: Economy, Ethics, Environment (April 19-21, 2021, Toruń, Poland). 


\section{Appendix}

\section{Table 1.}

Changes in the capital adequacy ratios of banks and credit institutions included in Basel III (in \%)

\begin{tabular}{|c|c|c|c|}
\hline Capital adequacy ratio & Formula & Basel II: minimum level (in \%) & Basel III: minimum level (in \%) \\
\hline $\begin{array}{l}\text { common equity Tier } 1 \\
\text { ratio (CETl capital) }\end{array}$ & $\frac{\text { common equity Tier } 1}{\text { total risk exposure }}$ & 2.0 & 4.5 \\
\hline Tier l capital ratio & $\frac{\text { Tier l capital }}{\text { total risk exposure }}$ & 4.0 & 6.0 \\
\hline $\begin{array}{l}\text { total capital ratio (Tier } 1 \\
\text { capital and Tier } 2 \text { capital) }\end{array}$ & $\frac{\text { own fundsl }}{\text { total risk exposure }}$ & 8.0 & 8.0 \\
\hline
\end{tabular}

Source: Own preparation.

Table 2.

Capital buffers in the Polish legal system compared to CRD IV/CRR package (in \%)

\begin{tabular}{|c|c|c|c|c|}
\hline & $\begin{array}{c}\text { Countercyclical } \\
\text { Conservation Buffer } \\
\text { (CCyB) }\end{array}$ & $\begin{array}{c}\text { Global Systemically } \\
\text { Important Financial } \\
\text { Institution Buffer } \\
(\mathrm{G}-\mathrm{SII})\end{array}$ & $\begin{array}{c}\text { Other Systemically } \\
\text { Important Financial } \\
\text { Institution Buffer } \\
\text { (O-SII) }\end{array}$ & $\begin{array}{c}\text { Systemic Risk Buffer } \\
\text { (SRB) }\end{array}$ \\
\hline $\begin{array}{l}\text { CRD IV/ } \\
\text { CRR package }\end{array}$ & $0-2.5$ & $1-3.5$ & $0-2$ & $>1$ \\
\hline $\begin{array}{l}\text { regulations } \\
\text { implemented } \\
\text { in the Polish } \\
\text { legislation }\end{array}$ & 0 & - & $\begin{array}{l}12 \text { other systemically } \\
\text { important institu- } \\
\text { tions were identified. } \\
\text { The buffer rate was set } \\
\text { at a level between } 0 \% \\
\text { and } 0.75 \%\end{array}$ & $\begin{array}{l}\text { the buffer rate of } 3 \% \text { is } \\
\text { applicable to all expo- } \\
\text { sures with the head- } \\
\text { quarter in Poland }\end{array}$ \\
\hline
\end{tabular}

Notes:

* In March 2020, due to the coronavirus pandemic, the systemic risk buffer in Poland was withdrawn under the Regulation of the Minister of Finance repealing the ordinance on the systemic risk buffer (2020).

Source: Own preparation.

Table 3.

Internal consistency of the scale

\begin{tabular}{lc}
\hline \multicolumn{1}{c}{ Construct } & $\alpha-$ Cronbach \\
\hline financial safety of the bank & 0.8230 \\
\hline
\end{tabular}

Source: Own preparation. 
Scheme 1 .

Financial safety of credit institutions under Basel III

\begin{tabular}{|c|c|c|c|}
\hline \multicolumn{4}{|c|}{ new regulatory tools for the financial safety of credit institutions } \\
\hline & & 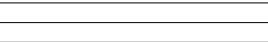 & \\
\hline \multicolumn{2}{|c|}{ prudential instruments } & \multicolumn{2}{|c|}{$\begin{array}{l}\text { state-level macroeconomic policy: } \\
\text { macroprudential supervision }\end{array}$} \\
\hline & 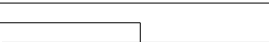 & & \\
\hline $\begin{array}{l}\text { new microprudenial } \\
\text { regulations: } \\
\text { - higher capital } \\
\text { requirements } \\
\text { - improvement } \\
\text { of the quantity and } \\
\text { the quality } \\
\text { of the bank capital } \\
\text { - implementation } \\
\text { of the liquidity } \\
\text { requirements } \\
\text { - implementation } \\
\text { of the leverage ratio }\end{array}$ & \begin{tabular}{|c} 
capital buffers: \\
- Countercyclical \\
Conservation Buffer \\
- Systemically \\
Important Financial \\
Institutions Buffers \\
- Systemic Risk Buffer
\end{tabular} & $\begin{array}{l}\text { macroprudential } \\
\text { instruments applicable } \\
\text { to the particular credit } \\
\text { instituions }\end{array}$ & $\begin{array}{l}\text { macroprudenial } \\
\text { instruments applicable } \\
\text { to the whole banking } \\
\text { system }\end{array}$ \\
\hline
\end{tabular}

Source: Own preparation.

\section{Chart 1.}

After the global financial crisis, the number of prudential regulations applied in banks has risen $(\%)$

60

50

50

45

40

30

20

10

0

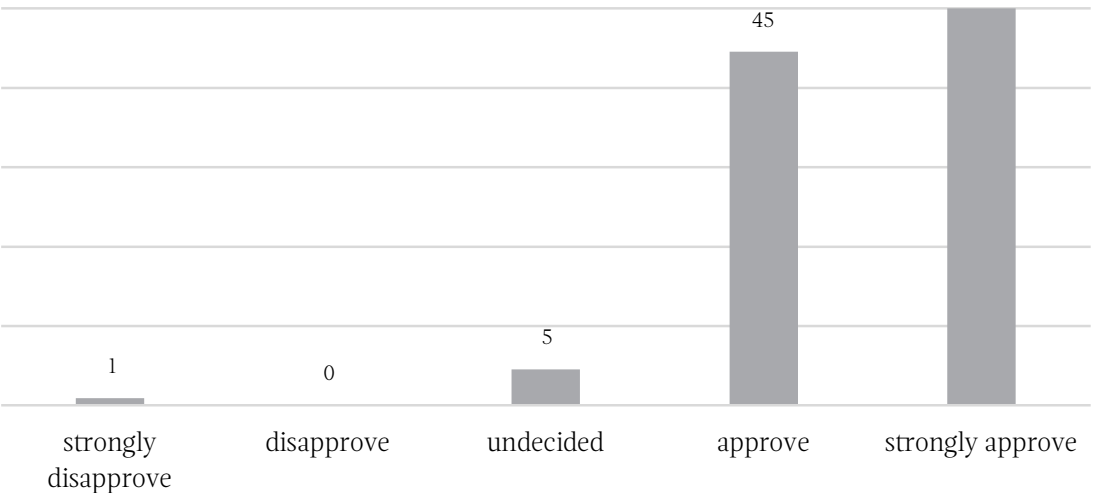

Source: Own preparation based on survey results. 


\section{Chart 2.}

Introduction of the new prudential standards in banks helps reducing the intensity of the systemic risk (\%)

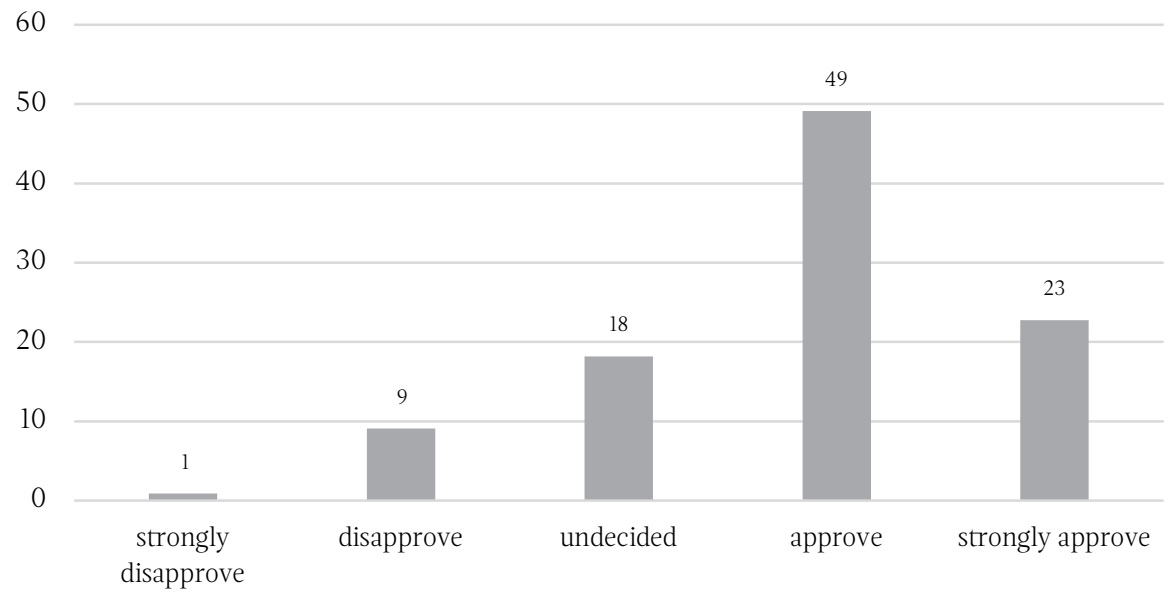

Source: Own preparation based on survey results.

\section{Chart 3.}

New prudential regulations increase the level of bank capital (\%)

60

50

49

40

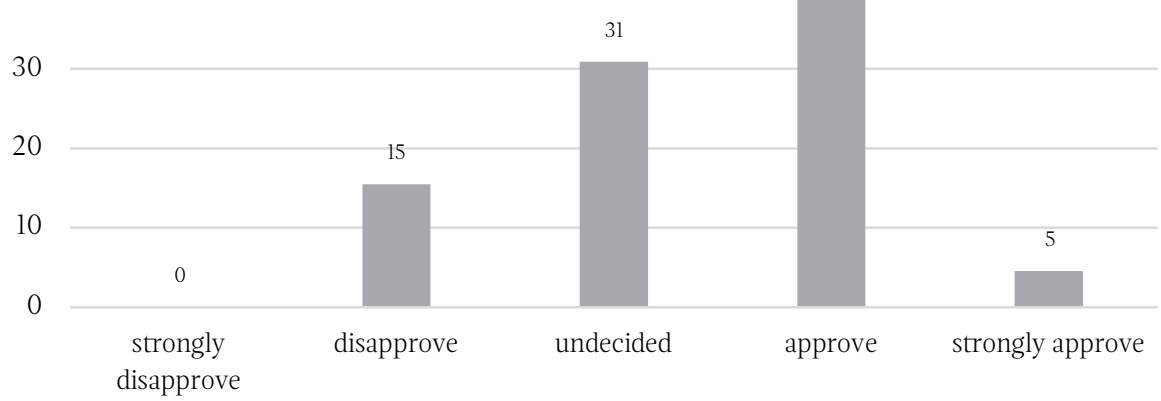

Source: Own preparation based on survey results. 


\section{Chart 4.}

New prudential regulations contribute to the change in the structure (quality) of bank capital (\%)

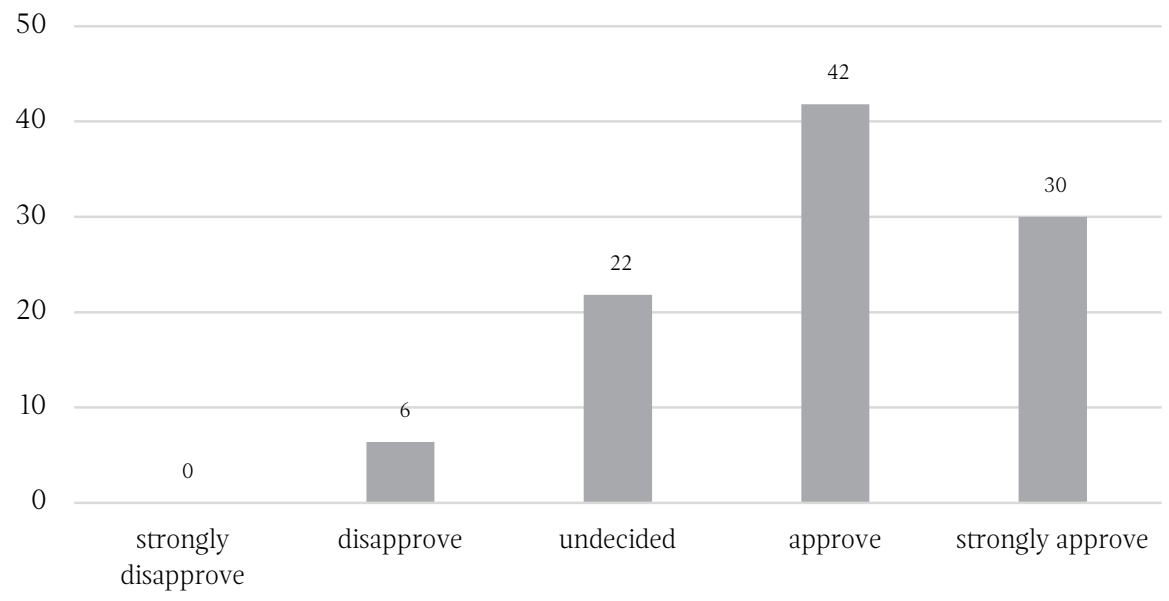

Source: Own preparation based on survey results.

\section{Chart 5.}

New prudential regulations contribute to the increase of the capital adequacy (\%) 60

50

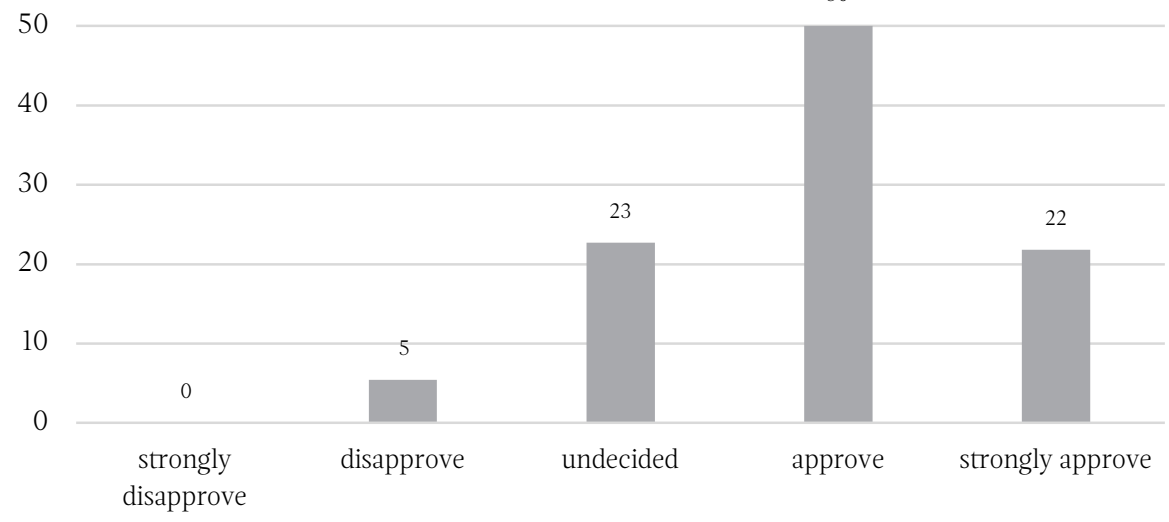

Source: Own preparation based on survey results. 


\section{Chart 6.}

Under the influence of new prudential regulations, the interest in transferring risk in banks is rising (\%)

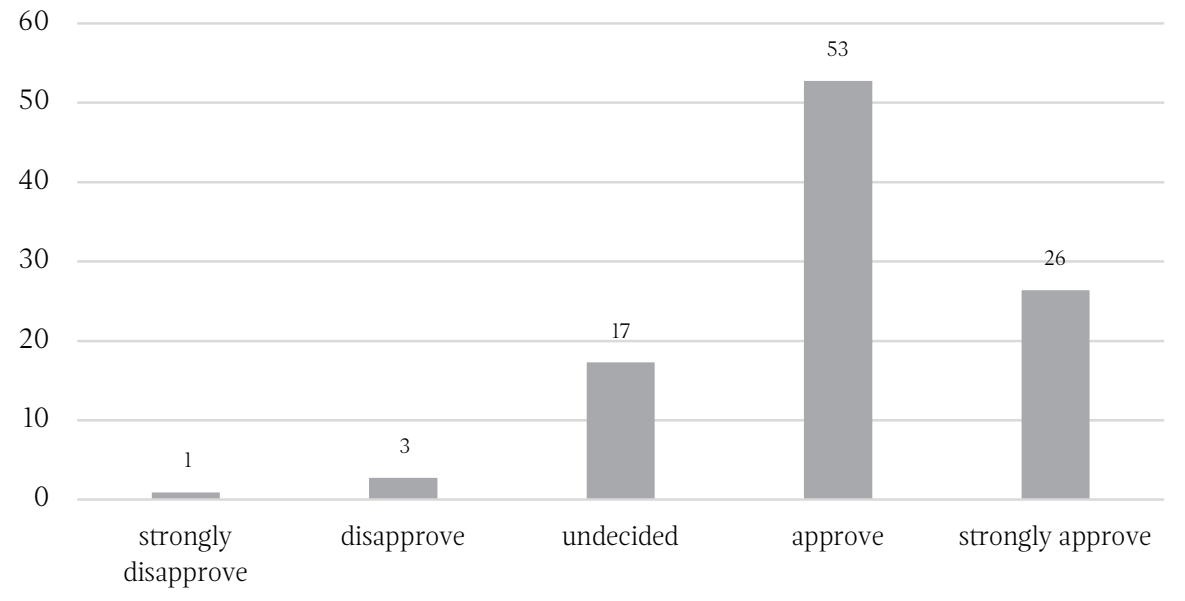

Source: Own preparation based on survey results. 
